\title{
A CENA LITERÁRIA \\ E A CENA ANALÍTICA
}

Maria Luiza Ramos

UFMG

\begin{abstract}
RESUMO
Retomando um tema polêmico, o objetivo deste ensaio é mostrar os tópicos em que convergem a cena literária e a cena analítica, considerando também o ponto em que ambas as cenas divergem. Para isso foram focalizados: a questão da verdade na poesia, aí compreendida a ficção; a unidade do espaço e do tempo; a unidade indivíduo; a errância entre o saber e a verdade; o sujeito suposto saber; a transferência; a repetição; o significante e, finalmente, a interpretação.
\end{abstract}

\section{PALAVRAS - CHAVE}

verdade, unidade tempo/espaço, transferência, significante, interpretação

"Ora (direis) ouvir estrelas!...".

\section{DA PROPOSTA}

Foi um poeta quem pela primeira vez disse: "Je est um autre" (Eu é um outro). Isto foi o que confidenciou Rimbaud em uma carta a um de seus mestres, confirmando mais uma vez como a arte se antecipa às teorias científicas. Essa é uma frase feliz, que se tornou até mesmo uma "fórmula", como a chamou Philippe Lejeune, ao fazer dela o título de um de seus livros.

O fato de eu colocar lado a lado a cena literária e a cena analítica não significa, porém, que vá estabelecer um paralelo, pois se são muitas as convergências, ambas as cenas divergem em questões fundamentais, uma vez que o texto é um produto acabado, cujo autor está ausente, e a fala do analisando evolui, estando presente o seu autor. Assim, respeitando as diferenças, vou tratar a seguir dos seguintes tópicos, tomando o discurso literário como referência: a questão da verdade na poesia, aí compreendida a ficção; a unidade do tempo e do espaço; a unidade indivíduo; a errância entre o saber e a verdade; o sujeito suposto saber; a transferência; a repetição; o significante e, finalmente, a interpretação.

Cultivando ou não o gosto pela Literatura, as pessoas, em geral, já possuem uma grande quantidade de informações sobre estes e aqueles autores, bem como sobre suas obras, seja poesia, romance, conto ou ensaio. De Literatura todo mundo sabe, bem ou mal, 
do que se trata, ainda que não se tenha feito um aprendizado específico. Aliás, nem é mesmo preciso aprender. Não no sentido corrente que registram os dicionários: "Tornar-se apto ou capaz de alguma coisa". E, como vivemos sob o jugo da razão, é sempre de um modo intelectual que esse "aprender alguma coisa" é considerado: como acumulação de conhecimentos.

Mesmo que não se tenha a paixão da etimologia, como era o caso de Borges, é sempre útil, entretanto, recorrermos à palavra no seu sentido original, que vai se tornando esquecido sob as diversas acepções que o uso lhe vai impondo. Assim, apreendo (ere) é, em latim, a forma poética de aprehendo (ere) - colher, tirar de, fazer seu, donde o apreender ter se tornado para nós o apossar-se, inclusive de bens materiais.

Mas o Aurélio registra também uma frase das Páginas Recolhidas, a de número 165, em que Machado de Assis observa: "Comecei a aprender a parte do presente que há no passado e vice-versa." Esta digressão tem, pois, um objetivo: a Literatura pode aprenderse, no sentido em que é possível a acumulação de conhecimentos, mas o que mais nos importa aqui é, antes, apreendê-la. E como o termo Literatura é muito vago, abrangendo tudo o que se escreve em matéria de Ciência e Filosofia, vou falar daqui por diante de poesia, mesmo que se trate de uma página de ficção. Esse "mesmo que" não traduz, porém, uma concessão à ficção. Pelo contrário: mais uma vez temos de desvestir o termo da banalização a que o reduziu o uso corrente, para encontrarmos o sentido original, ligado ao verbo latino fingo (ere), que, como o grego poiéo (ein), significava fazer, criar. Talvez pelo fato de se tratar de um fazer manual - o dar forma à argila, por exemplo - essa criação não merecesse o prestígio da poiesis grega, cujo instrumento era o logos. Mas foi no sentido do fazer artístico, do moldar a cera para criar uma representação da realidade, "fingindo-a", que a palavra ficção se propagou, desenvolvendo-se como mimesis e se revestindo, pois, do sentido popularizado e depreciativo do termo, ou seja, como imitação. Agora mesmo falei em desvestir o termo e foi esse mesmo verbo - entkleiden, em alemão - o que Freud empregou para referir-se à análise do sonho, ao trabalho de desvestir a roupagem de que se reveste o sonho - a Einkleidung -, a configuração, a fábula, a elaboração formal resultante do deslocamento. Tal operação é, pois, essencial à produção onírica, uma vez que, sendo o sonho uma ficção, esse é o lugar em que a verdade se faz possível de apreender.

\section{DA VERDADE E DA FICÇÃO}

A relação entre verdade e ficção é um dos temas privilegiados da Filosofia, sendo que El concepto de verdad en Lacan vem a ser o título da tradução espanhola de um texto de Derrida. E Lacan, por sua vez, reporta-se freqüentemente a Heidegger, que pronunciou, cerca de dez anos antes, uma conferência sobre a essência da verdade - Von Wesen der Wahrheit.

Foi a partir da obra de ficcionistas que Lacan mais discutiu esse problema. São muito conhecidos, por exemplo, o Seminário que dedicou ao conto A carta roubada, de Edgard Allan Poe, bem como os comentários sobre a obra de Jean Delay, La jeunesse de Gide. Fixando-se nesses textos, Derrida deixa entrever o quanto são fluidas as fronteiras entre os conceitos de verdade e ficção, pois, ao mesmo tempo em que aqui se lê que "uma literatura 
pode produzir, pôr em causa, uma verdade", ${ }^{1}$ também ali se proclama que é a verdade que "possibilita a própria existência da ficção". ${ }^{2}$ Tal concepção, aliás, já tinha sido formulada por Edmund Husserl, que, já em 1913, ${ }^{3}$ foi ao âmago da questão, colocando, pois, em prática o seu lema $Z u$ den Sachen selbst (às próprias coisas):

"Se se ama os paradoxos, e com a condição de bem entender o sentido ambíguo sem se desrespeitar a estrita verdade, pode-se dizer que a ficção constitui o elemento vital da fenomenologia, como de todas as Ciências eidéticas; a ficção é a fonte em que se alimenta o conhecimento das 'verdades eternas'." (Tradução própria)

Freud não está longe disto, quando situa no sonho a estrada real para o inconsciente, do mesmo modo que Derrida repete que é através da ficção que a verdade se mostra, ao afirmar, com Heidegger, que a Dichtung (o dito poético, a ficção) é a manifestação da verdade, seu ser-revelado. E citando Lacan: "Há tão pouca oposição entre a Dichtung e a Wahrheit em sua nudez, que o fato da operação poética deve antes deter-nos nesse traço esquecido em toda verdade, tal seja, que ela se revela numa estrutura de ficção." ${ }^{4}$

Esse jogo da verdade, a que Derrida se refere de passagem, como a aletés heideggeriana, tem suas raízes no próprio vocabulário grego, pois, se alétheia-as significa verdade, aletéiaas quer dizer vida errante, o ir de um lugar a outro. E essa errância Heidegger considera o modo de ser do homem: ele não se move senão na errância, porque ele in-siste em existindo e assim se encontra desde sempre na errância. A essência da verdade é, pois, a liberdade. Não aquela que o homem possui, mas a que possui ao homem e faz possível a verdade como descobrimento do ente. Ela é a essência originária da verdade, do reino do mistério na errância.

Não deixa de ser curioso o fato de que a verdade, alétheia-as, seja palavra formada da raiz léthe, que significa esquecimento. E não era esse o nome de um rio, no Hades, de cujas águas as almas bebiam, esquecendo-se de toda a vida anterior? (Veja-se em português letárgico e letal). Como o prefixo a é de privação, o sentido de alétheia é de desesquecimento, e a saída do esquecimento equivale a descobrimento. Eu me referi ao jogo de conceitos entre verdade e errância (donde o errar e o erro como negação da verdade) e é possível que toda essa discussão filosófica, que conduz ao paradoxo, se prenda à afinidade de significantes - alétheia e aletéia -, pois essa segunda palavra é da família do verbo aletêuo (aláomai), que significa errar, e nada tem a ver com a raiz anterior. É claro que estou tomando o significante no sentido tradicional: seqüência de sons articulados ligada a um determinado conceito. Ainda que possa parecer fantasiosa tal relação - e sabe-se quantas falácias existem no campo da etimologia - isto não é raro no grego: duas palavras de conceitos diversos acabarem por se confundir em virtude da afinidade sonora, mesmo havendo pequenas divergências em sua grafia.

\footnotetext{
${ }^{1}$ Derrida. El concepto de verdad en Lacan, p. 14.

2 Derrida. El concepto de verdad en Lacan, p. 26.

${ }^{3}$ Husserl. Idées Directrices pour une phénoménologie, I, p. 227.

${ }^{4}$ Derrida. El concepto de verdad en Lacan, p. 87
} 


\section{DO TEMPO E DO ESPAÇO}

Ao contrário de conceitos que se querem rigorosos no contexto da Filosofia, encontramo-nos, pois, diante de uma fluidez conceptual que nos leva de volta a Machado de Assis, quando quer aprender a parte do presente que há no passado e vice-versa, buscando a verdade na errância da emoção. Aliás, é essa a atitude do Dom Casmurro, querendo atar as duas pontas da vida, e esse foi também o comportamento do homem Machado, o viúvo que manteve a casa como era em vida da esposa - ficcionalizando a realidade através de artifícios, como a cesta de bordados junto à cadeira de balanço, o prato na mesa.

O que Machado de Assis enuncia numa proposição, Fernando Pessoa vivencia na poesia, a propósito de uma melodia. "Pobre velha música", diz o primeiro verso, e o poema termina assim:

\section{Com que ânsia tão raiva \\ Quero aquele outrora! \\ E eu era feliz? Não sei: \\ Fui-o outrora agora. ${ }^{5}$}

Tal presentificação do passado, explicitada pelo Poeta, encontra-se implícita em muitos poemas, que, além de promoverem a anulação do tempo cronológico, destroem também o espaço euclidiano. Esta é uma característica da poesia: ser tanto uma linguagem condensada quanto promover uma condensação. Neste caso, condensação do tempo e do espaço. E não é por coincidência que Dichtung, em alemão, é um nome derivado de dicht, denso, e que Verdichtung designa a condensação onírica.

Detenhamo-nos neste poema de João Cabral - um dos muitos Cemitérios Pernambucanos, o de Nossa Senhora da Luz:

\footnotetext{
Nesta terra ninguém jaz, pois também não jaz um rio noutro rio, nem o mar é cemitério de rios.

Nenhum dos mortos daqui vem vestido de caixão. Portanto, eles não se enterram, são derramados no chão.

Vêm em redes de varandas abertas ao sol e à chuva. Trazem suas próprias moscas. O chão lhes vai como luva.

Mortos ao ar livre, que eram, hoje à terra-livre estão. São tão terra que a terra nem sente a sua intrusão. ${ }^{6}$
}

\footnotetext{
${ }^{5}$ Pessoa. Poesias, p. 98.

${ }^{6}$ Cabral. Duas águas, p. 159.
} 
Através de pequenos recursos sintáticos, como o uso de dêiticos - palavras que os ingleses chamam de shifters, porque trapaceiam, enganam - tanto com relação ao espaço, "nesta terra", "os mortos daqui", quanto ao tempo, "hoje à terra-livre", o Poeta nos faz participar de uma realidade a que ele não apenas se refere, representando-a, mas a qual ele recria, apresentando-a, presentificando-a no aqui e no agora. Neste texto de Gilberto Freyre, sobre o mesmo tema, é tudo diferente:

"Nestas páginas - simples tentativa para ver de perto alguns traços da fisionomia social do Nordeste, e em que somos às vezes obrigados a nos repetir - lembraremos que o trabalho de engenho e de trapiche de açúcar, quase não é mais de negro - já não existe, talvez, negro verdadeiramente puro na região - mas de cabra, de mestiço, de mulato. E entretanto é talvez um trabalho mais penoso do que no tempo da escravidão. (...) Segundo documento oficial - Aspectos da Economia Rural Brasileira - há no Nordeste "propriedades em que os trabalhadores iniciam os seus serviços com o romper do sol e só os deixam ao ocaso, com pequenos intervalos para o almoço e uma merenda." E todo esse excesso de esforço físico, dos trabalhadores de açúcar, dos cabras de engenho, dos negros de bagaceira, a despeito das condições de vida terrivelmente desfavoráveis: "quase nus e minados por toda sorte de mazelas e vícios”; morando em "choupanas miseráveis". (...) A verdade é que talvez em nenhuma outra região do Brasil a extinção do regime de trabalho escravo tenha significado tão nitidamente como no Nordeste da cana de açúcar a degradação das condições de vida do trabalhador rural e do operário. A degradação do homem." (Ênfase adicionada) ${ }^{7}$

Por mais realista que tenha sido essa exposição, cheia de interpolações explicativas e de citações com autoria documentada, há uma distância entre o texto e a realidade a que se refere o Autor - a linguagem tem mesmo aí uma função referencial - e essa distância não se dá apenas com relação ao escritor, mas atinge o leitor, ficando ambos fora dos fatos narrados. Isto, porém, não acontece no poema de João Cabral, em que se pode dizer que há um "espaço galáctico", em que a concepção tradicional de espaço e tempo é quebrada na vivência de um "aqui e agora".

Comentando um verso de Hölderlin - Mas eis o dia! Eu o esperava, o vi chegando -, Heidegger pergunta: "Eis - qual é o tempo desse eis? É o período dos anos 1800, em que apareceu o poema: Esse eis nomeia certamente o tempo em que Hölderlin diz: Eis o dia! Certamente esse eis nomeia o tempo de Hölderlin e nenhum outro." Mas continua: "um tal tempo não se deixa jamais datar e não é mensurável em número de anos ou divisões por séculos".

\section{DO LUGAR PSÍQUICO}

Como faz Nasio com relação à cena analítica, pode-se também perguntar: onde fica o dentro, onde fica o fora de um poema? Onde fica o presente, onde fica o passado numa experiência estética? Isto, porém, não é tudo. Além da questão do tempo e do espaço, há a relação entre autor e leitor. Já uma vez observei: o poeta tem diante de si a folha em branco, a caneta ou o lápis, o computador. O poeta está só. Entretanto, a sua palavra repercute e instaura o Outro - interlocutor abstrato que o ouve em silêncio, numa escrita

${ }^{7}$ FREYRE. Nordeste, p. 256. 
feita de conivência. E é essa cumplicidade que estimula a comunicação, desencadeia a linguagem, fazendo com que se introduza na racionalidade da palavra programada o aleatório do dito até então, ou para sempre, insuspeitado. A circunstância da escrita empresta ao eu um nós. E essa ausência/presença vem a ser o suporte de uma negatividade em que a produção literária se torna possível. Entretanto, como na circunstância da cena analítica, baseada, inversamente, na presença/ausência de uma escuta solidária e cúmplice, também na escritura, além de provocar o rompimento do tempo cronológico e do espaço euclidiano - condição salientada por Nasio com relação ao processo analítico -, dá-se também a quebra da "unidade indivíduo".

No texto de Gilberto Freyre, as citações são transcritas entre aspas, respeitando-se a sua autoria. Num texto poético ocorrem também citações, mas são antes apropriações, de tal forma que somente o leitor que tenha conhecimento do texto incorporado pode reconhecê-lo, promovendo a sua inserção no ato da leitura e tornando-o parte integrante do novo texto. Num outro Cemitério Pernambucano, por exemplo o de São Lourenço da Mata, diz o Poeta:

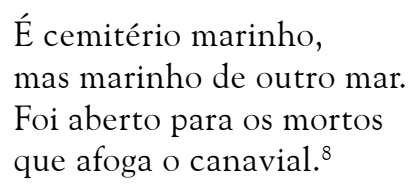

O "marinho" denota a localização do cemitério, no litoral pernambucano. Mas tratase de um "marinho de outro mar", e essa conotação nos leva a outras terras, a um outro autor: Le cimetière marin é o título de um poema de Valéry, cuja paisagem geográfica e humana é completamente diferente, prevalecendo aí a beleza, a paz, os valores afetivos e espirituais. Do mesmo modo, uma relação intertextual se dá no caso da cena analítica, em que o analisando incorpora à sua fala discursos alheios, mas já então seus.

No ato da leitura, somente quando deixamos de seguir as nossas referências e expectativas conscientes e nos abandonamos à atividade mental inconsciente - como recomendou Freud aos psicanalistas - é que logramos o inconsciente do texto. Quando nos deixamos surpreender, indo atrás das palavras, ao invés de dirigi-las. É esse um momento transferencial privilegiado, que faz de autor e leitor um único lugar psíquico.

\section{DA TRANSFERÊNCIA}

Se a verdade é uma errância, na cena analítica essa errância se dá também entre o saber e a verdade: um saber/não saber do analisando, dirigido a um suposto saber do analista. Sendo a condição de uma análise, a transferência é também a condição de um ato de escritura. A propósito, lembro o quanto foi fundamental a contribuição de Lacan à teoria freudiana da transferência. Como observou Jacques-Alain Miller nas Conferências Caraquenhas: ${ }^{9}$ fazendo do suposto saber do analista o fundamento transfenomênico da

\footnotetext{
${ }^{8}$ Cabral. Duas águas, p.157.

${ }_{9}^{9}$ Miller. Percurso de Lacan.
} 
transferência, Lacan desviou o foco do processo transferencial, do analista como pessoa para o analista como significante. Do mesmo modo o leitor, como significante do Outro, é também detentor de um sujeito suposto saber, numa relação transferencial.

A angústia do poeta, a quem é dirigida? Quando Fernando Pessoa pergunta:

Não meu, não meu é quanto escrevo.

A quem o devo? De quem sou o arauto nado?

Por que, enganado,

julguei ser meu o que era meu? ${ }^{10}$

Ou então:

$$
\begin{aligned}
& \text { Por que é que um sono agita } \\
& \text { em vez de repousar } \\
& \text { o que em minha alma habita } \\
& \text { e a faz não descansar? }{ }^{11}
\end{aligned}
$$

Drummond, num longo poema interrogativo:

$$
\begin{aligned}
& \text { Mas que coisa é homem } \\
& \text { que há sob o nome: } \\
& \text { uma geografia? } \\
& \text { um ser metafísico? } \\
& \text { uma fábula sem } \\
& \text { signo que a desmonte? }{ }^{12}
\end{aligned}
$$

E como não lembrar aqui a insistência da pergunta em "E agora, José?”. ${ }^{13}$ Certamente, não é a esse outro, especular, que o Poeta endereça a pergunta, mas ao Outro, o sujeito suposto saber. Se, como observam Danielle e Michel Silvestre, o analisando não interroga as estrelas, enquanto dirige a sua fala ao lugar do Outro, ${ }^{14}$ é igualmente a esse Outro que o poeta se dirige, mesmo quando se põe a interrogar as estrelas:

"Ora (direis) ouvir estrelas! Certo

perdeste o senso." E eu vos direi, no entanto, que para ouvi-las, muita vez desperto e abro as janelas, pálido de espanto...

E conversamos toda a noite, enquanto a Via-láctea, como um pálio aberto, cintila. E, ao vir do sol, saudoso e em pranto, inda as procuro pelo céu deserto.

Direis agora: "Tresloucado amigo! Que conversas com elas? Que sentido têm o que dizem, quando estão contigo?

\footnotetext{
${ }^{10}$ Pessoa. Poesias, p. 152.

${ }^{11}$ Pessoa. Poesias, p. 171

${ }^{12}$ Drummond de Andrade. Poesia e prosa, p. 276.

${ }^{13}$ Drummond de Andrade. Poesia e prosa, p. 77.

${ }^{14}$ Silvestre. Le Transfert, c'est l'amour qui s'adresse au savoir, p. 129.
} 
E eu vos direi: "Amai para entendê-las!

Pois só quem ama pode ter ouvido

capaz de ouvir e de entender estrelas." 15

No diálogo que se trava nesse soneto, o outro é antes o duplo, que aí aparece como o lado racional do sujeito, o superego pronto a censurar-lhe qualquer desvio do senso comum. Quanto às estrelas, elas, sim, são a metáfora do sujeito suposto saber a que se dirige a angústia do Poeta, que pela madrugada ainda as procura, "em pranto". E qual é o fator do mencionado entendimento, ao final do poema? $\mathrm{O}$ amor: "Amai para entendêlas." Assim, pois, como o Poeta abre as janelas "pálido de espanto", o analisando escancara a sua vida, sem nada entender do que consigo se passa. E esse encontro se repete, muitas vezes, sob o pálio aberto do analista que, situado necessariamente em um lugar tão distante quanto a Via-Láctea, vai iluminando aqui e ali a sua ignorância. Trata-se de uma pontuação, que ocorre também na situação da leitura. E como a interpretação se faz através da cadeia significante, vamo-nos deter primeiramente na repetição, pois, se sem amor não há transferência, também sem repetição não há significante.

\section{DA REPETIÇÃO}

Ao contrário das atividades de controle, nas quais o homem começou a atuar sobre as forças naturais, gerando a tecnologia e as ciências econômicas; ou sobre o próprio homem, o que conduziu à sociologia e às ciências políticas, ou, ainda, sobre as forças sobrenaturais, dando origem à magia e às religiões, as atividades lúdicas e artísticas não são pragmáticas, tendo um fim em si mesmas, visando à sua própria perfeição. E além dessa diferença fundamental, há um traço que as caracteriza, assinalando a sua especificidade: é o mecanismo repetitivo. Não há jogo sem repetição, do mesmo modo que, pela mimesis, o artista repete a natureza e os sentimentos humanos, recriando-os. $\mathrm{O}$ fato de as atividades lúdicas e artísticas terem um fim em si mesmas não impede, entretanto, que um quadro, por exemplo, possa representar milhões. Entretanto, no ato de o fazer, de lidar com tela e tintas, a única coisa que importa ao artista é a perfeição das formas e das cores. Já a obra acabada é um produto e, como qualquer outro, tem lugar no mercado. Do mesmo modo, numa partida de futebol, por exemplo, o suor dos jogadores produz emoções na torcida, gera muito dinheiro na indústria do futebol e na mídia, mas durante o jogo nada mais existe senão a perfeição dos passes na meta do gol. E uma vez conquistado este, a bola volta ao meio do campo, para que se comece tudo de novo. Tudo igual. Tudo diferente.

Desde Aristóteles, que privilegiava a unidade na variedade, a música, a poesia, a dança, a pintura e a arquitetura sempre se renderam à sedução da repetição, seja sob a forma de variações sobre um tema, seja numa seqüência de versos e de estrofes, de movimentos, de volumes, de formas e de cores, ou na sucessão de arcos e colunas.

Se no contexto analítico a repetição é indício do retorno do recalcado, na música e na poesia a repetição é a sua razão de ser. Desde o refrão, o paralelismo é um traço distintivo das composições populares, explícito também na literatura oral, em que uma história

${ }^{15}$ Bilac, Via Láctea. Brayner. Poesia no Brasil, p. 310. 
apresenta em geral três episódios que correm paralelos, invertendo-se a expectativa ao final. Na ficção e no drama, dá-se muitas vezes um contraponto entre a história atual e uma outra de diferente contexto, ilustrando-se mutuamente. No romance, por exemplo, uma história pode ser lida simultaneamente em palavras e num quadro que pende da parede, ou numa determinada música que pontua a narrativa com insistência. Isto foi o que André Gide chamou de mise-en-abîme, a propósito de seu romance Os moedeiros falsos, em que a personagem escreve um romance que vem a ser, afinal, aquele que o autor conclui. E não se podem esquecer os deslocamentos da narrativa, que dão lugar a isotopias aparentemente desconexas com relação à trama central. Quanto ao verso, sobretudo, a própria palavra já diz de um discurso que não é linear, que vai e que volta - versus -, se interrompe e recomeça, repetindo padrões métricos, rimas, aliterações, assonâncias, anáforas e unidades estróficas. Mesmo a poesia moderna, que se libertou das amarras tradicionais e das formas fixas, apresenta cortes num discurso impulsionado, muitas vezes, tanto pelo sentido das palavras quanto pela sugestão de sua estrutura sonora, em que certos sons se repetem em variações. Trata-se de um processo que, apesar de tradicional, vem se vulgarizando pela facilidade de construção, pelo seu caráter de jogo. Um poema de Leminski, num livro em que o próprio título é uma paródia - La vie em close/c'est une autre chose -, explora a qualidade dos sons, como se observa a seguir:

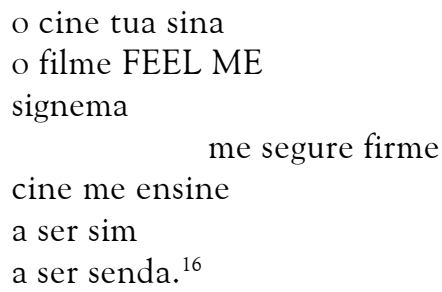

Esta é apenas uma pequena mostra de como as qualidades sonoras da palavra impulsionam o verso no eixo sintagmático do discurso, através de repetições que se articulam na estrutura. Tal insistência nos efeitos rítmicos da linguagem, se já era conhecida e até muito explorada pelos poetas romanos, teve o seu momento de glória em fins do século passado, com o simbolismo. De la musique avant toute chose era a máxima de Verlaine, que se comprazia com a musicalidade dos versos.

Trata-se de uma sedução de sons afins, que repercutiu entre nós em poemas de até muito mau gosto, como alguns dos mais conhecidos de Cruz e Sousa, por exemplo. E dessa sedução não estão livres os melhores poetas, com a diferença de que, ao se aperceberem de que estão sendo seduzidos pela musicalidade, dão uma guinada no verso, como fez Carlos Drummond de Andrade em Elegia:

Amor, fonte de eterno frio, minha pena deserta, ao fim de março, amor, quem contaria?

E já não sei se é jogo, ou se poesia. ${ }^{17}$

\footnotetext{
${ }^{16}$ Leminski. La vie em rose c'est une autre chose, p. 41.

${ }^{17}$ Drummond de Andrade. Prosa e verso, p. 259.
} 
Mas é raro que essa percepção crítica aflore ao curso da escrita. Comentando a freqüência de uma mesma imagem acústica em poemas de autores diversos, transcrevi certa vez uma pequena estrofe latina - Nula unda/tam profunda/quam vis amoris/furibunda ${ }^{18}$ - para mostrar como esse efeito, de certa forma onomatopaico, surgia em poetas como Manuel Bandeira - aonde anda/a onda?/ainda/ainda anda /ainda anda/aonde?/a onda/a onda, do mesmo modo que em Drummond, no primeiro verso de um soneto - Onda e amor, onde amor, ando indagando - e em João Cabral, na última estrofe do Cemitério de São Lourenço da Mata:

\section{Pois que os carneiros de terra parecem ondas de mar não têm nome: onda por onda onde se viu batizar?}

Quanto a esse poeta, ocorreu um fato interessante. Eu lhe tinha enviado um exemplar da Fenomenologia da obra literária, não só como agradecimento ao Duas Águas, que ele me havia mandado, mas também porque era um dos poetas de que me servira para ilustrar minhas reflexões teóricas. Pois mais tarde, na reedição desse poema, João Cabral o modificou, de modo a minimizar a imagem, ficando assim os dois últimos versos: "não levam nomes: uma onda/onde se viu batizar?"

E que dizer das histórias infantis, que as crianças exigem serem absolutamente iguais às contadas ontem e anteontem? A propósito, Lacan diz que há um segredo no lúdico, e esse segredo é a diversidade mais radical, constituída pela própria repetição. ${ }^{19}$ Algo semelhante ao que ainda há pouco chamei de mecanismo repetitivo nas atividades lúdicas e artísticas também se verifica no comportamento psicológico, tendo Freud mencionado um "automatismo de repetição", discutido num texto-chave de seus escritos - Além do princípio de prazer. E Lacan, retomando esse tema no Seminário da Carta Roubada, e sobretudo no Seminário XI, no capítulo intitulado "Linconscient et la répétition", aventurase na etimologia de Wiederholen - palavra alemã composta de wieder, de novo, e holen, buscar, voltar -, afirmando que nada foi mais enigmático no texto freudiano do que esse termo que, segundo os etimólogos mais comedidos, é muito próximo do francês haler (do neozelandês): puxar por uma corda, um cabo, por exemplo na expressão chevaux de halage, cavalos de tração. Esse haler, diz Lacan, está também muito próximo do haler do sujeito, "que conduz sempre a sua manha (o seu truque) por um certo caminho de onde ele não pode sair. (lequel tire toujours son truc dans um certain chemin d'où il ne peut pas sortir." ${ }^{20}$ Tal incursão etimológica, Lacan a justifica pelo fato de se tomar comumente Wiederholung por mera repetição, como em Wiederholen Sie, bitte (Repita, por favor). No contexto analítico não se trata, porém, de uma repetição qualquer, mas daquela que é necessária, no sentido do que não pode ser de outro modo, do que está sendo trazido, submetido a uma determinada força.

Lacan vai de Freud a Aristóteles, para retomar o conceito de automaton, que ele relaciona com a cadeia do significante, e o conceito do que chama de tuché, que vai

\footnotetext{
${ }^{18}$ Ramos. Fenomenologia da obra literária, p. 40.

${ }^{19}$ LACAN. Le Séminaire, Livre XI, p. 60.

${ }^{20}$ LaCAN. Le Séminaire, Livre XI, p. 51.
} 
relacionar com o real. Lacan escreve essas palavras em itálico, o que indica serem de língua estrangeira. Mas em francês não há esse termo: tuché. Quanto a automaton, o termo tem, em grego, o mesmo sentido que veio até nós: o que se move por si mesmo, além de significar também fortuito, casual, espontâneo. Se a palavra tuché não é francesa, grega também não é. Existe, sim, esta outra: túche, es - o que se alcança por decisão dos deuses, ou por acaso. Como nome próprio, Túche significa a Fortuna, a Sorte, o Acaso. Assim, o significante exerce a sua função, que é desdobrar-se como que automaticamente, ou seja, independentemente da intenção do sujeito em dizer isto ou aquilo. As palavras vão sendo puxadas por uma força inconsciente, uma tração, e dessa cadeia resulta, como que por acaso, o real. O significante em Lacan não é apenas o arcabouço sonoro de um determinado significado, como em Saussure, mas vem a puxar outro, e outros, numa cadeia em que um sentido passa a insistir.

Ao contrário do jogo articulatório dos poetas simbolistas, por exemplo, o qual se dirige sempre para diante, o jogo do significante, em Lacan, se dá no momento em que um determinado som se prende a outro que ficou atrás, sendo que esse point-de-capiton - esse capitonê - vai promover o curto-circuito de onde eclode o sentido.

Sendo metonímica, a cadeia do significante é também metafórica, e aí Lacan se distancia da retórica tradicional. Uma vez que o significante se repete por si mesmo, ele é uma produção inconsciente, que não se endereça a ninguém, não sendo, pois, percebida pelo analisando. E se o significante só é significante em relação a outro significante, não há necessidade de que ele se atenha à seqüência de sons articulados - à imagem acústica detectada por Saussure. A repetição pode dar-se com unidades semânticas, ou mitemas, exorbitando mesmo da semiótica lingüística, para enriquecer-se com outros sistemas semióticos não verbais, como os visuais, por exemplo, com os seus códigos de imagens; ou os cinéticos, por meio dos códigos gestuais e os de movimento em geral, bem como os químicos, com os códigos do olfato e do paladar. Ao analista é que cabe pontuar a repetição, o que leva a uma interpretação.

\section{DA INTERPRETAÇÃO}

Aqui chegamos a um ponto delicado. Sendo a análise um processo terapêutico, ela faz com que o analisando logre substituir, ele mesmo, o seu "saber" pela verdade, alcançando, pois, o preenchimento do seu não-saber num discurso pleno. São bem conhecidos os riscos da interpretação, que podem transformar o analista, de intérprete, em responsável pela angústia do paciente, ou até no causador dela.

E quanto ao texto literário? Como já lembrei, enquanto a relação analítica é dinâmica, evolui, estando presente o analisando, o texto é um produto acabado que não sofre modificação e está ausente o autor. Em geral não ocorre qualquer diálogo fora do texto, entre leitor e autor. Este, é possível que nunca venha a tomar conhecimento de determinada leitura, podendo mesmo ter pertencido a uma outra época. Quando há retorno, porém, o diálogo pode ser muito gratificante, como no caso do meu ensaio sobre a presença da Árvore Cósmica na poesia de Drummond.

O Poeta, se tinha a fama de arredio - o que era necessário para resguardar a sua privacidade - cultivava, porém, a prática da correspondência. Sabe-se que não deixava sem resposta qualquer trabalho que focalizasse a sua obra. Tanto assim que, mesmo quando 
não nos conhecíamos pessoalmente, lá pelos anos cinqüenta, recebi através do jornal em que havia sido publicado um artigo meu estas palavras carinhosas: "Esta carta vai como garrafa jogada ao mar..." Depois disso, e de encontros casuais aqui e no Rio, onde freqüentávamos a Livraria Leonardo Da Vinci, eram telegramas e cartas a cada novo artigo. E eu recebia por vezes a gentileza de um telefonema, quando se apressava a pronunciar-se sobre os trabalhos. No caso, porém, daquele ensaio sobre a Árvore, além de telefonar mandou-me ele uma carta, que transcrevi em Interfaces. A importância desse documento - e também a razão por que foi ele transcrito - reside no fato de que a carta é mais do que um gesto de cordialidade: contém uma poética, em que Drummond discute o processo criador a partir da minha leitura, e confessa que não percebera nunca o sentido mítico da árvore em sua poesia:

"Sabe que aprendi muitas coisas a meu respeito, reveladas por você?

Eu não me dava conta da insistência ou permanência da coisa natural árvore na minha poesia, que considerava apenas como objeto circunstancial e não com o significado cósmico que você lhe aponta. Sabe como é que a gente compõe?

Sem saber que está fazendo uma segunda verbalização da coisa descrita ou narrada... E essa segunda verbalização é, no fundo, por mais misterioso que pareça, a verdadeira. A outra: um exercício direto de exposição de coisas, exteriores ou interiores. Você me deu o segundo sentido da poesia que no fundo é o primeiro. Fiquei feliz de ser assim "contado" a mim mesmo..." Grifo adicionado ${ }^{21}$

E o meu trabalho de leitura foi o de pontuar, ao longo da obra, os significantes relativos ao mito da queda, à Árvore da Vida e à Árvore da Ciência do Bem e do Mal - mitemas que se repetiam no texto, se entrecruzavam num encadeamento que revelava uma dimensão universal em cada um dos poemas, paralelamente à sua unicidade como produto literário. A interpretação se deu num e por um texto, sem que houvesse qualquer processo junto ao autor, de modo que se tornasse possível a ele mesmo dar-se conta, paulatinamente, do que havia escrito. Tudo lhe foi revelado de uma só vez, o que não acontece na prática analítica.

Se o meu texto produziu um efeito positivo no poeta, já em outro autor ele provocou uma reação que, apesar de se ter manifestado a princípio de maneira entusiástica, acabou por se revelar defensiva. Foi o que aconteceu com Darcy Ribeiro. Empolgou-se com a análise que fiz do romance Maíra, ${ }^{22}$ chegando a repeti-la em palestras sobre a sua obra, em várias oportunidades. O que o seduziu foi sobretudo ver que Maíra, Isaías e Darcy, apesar de terem uma individualidade própria, eram personificações de um só sujeito, o que eu havia demonstrado através de um trabalho de texto, em que um mesmo discurso se repetia aqui e ali nas três personagens - três, porque, ao contrário de Oswald de Andrade, que expulsou uma personagem de um de seus romances, Darcy se mete no meio da narrativa para falar sobre a sua pessoa, como um metanarrador. Essa tentativa de desmitificar a ficção, no que ela pudesse ter de autobiográfico, resultou, entretanto, na reafirmação de uma fonte pessoal, inconsciente. Um anagrama com esses nomes próprios, em que a um $\mathbf{A}$ sucede um Í tônico, ratificou a análise. ${ }^{23}$

\footnotetext{
${ }^{21}$ Ramos. Interfaces, p. 58.

22 Ribeiro. Maíra.

${ }^{23}$ Ramos. Interfaces, p. 141
} 
Em O mulo, romance que sucedeu ao de estréia, Darcy se valeu desse motivo do sujeito dividido para fazer com que o narrador assumisse uma autodivisão, mas numa perspectiva diacrônica, através da memória:

"Eu, coronel Philogônio de Castro Maya, senhor dos Laranjos, (...) olho para trás e me vejo no que fui, na raiz. Aquele rapazinho (...) Que temos em comum eu no que hoje sou e ele, no que foi, volto a perguntar?"24

Pouco adiante, insiste nessa indagação: "Quem sou eu que aqui confesso? Isso que chamo eu é só meu eu de agora. Antes fui aquele menino e muita gente outra. Todos eram, na verdade, eu mesmo, mas muito disfarçados. ${ }^{25} \mathrm{E}$ logo:

"Estive pensando outra vez nos eus que fui. Fiquei horas aqui na sala do meio, imaginando todos nós sentados, ao redor da mesa, conversando, entre eles e comigo. Eu menino, eu rapaz, eu homem feito. Eu casado, eu viúvo. Eu tropeiro, eu muleiro, eu abridor do Vão. Eu, sentado bem no meio deles ficava comparando, vendo que cada um é diferente de mim e de todos os outros. Até mais diferentes somos entre nós, do que de quanta gente conheci, em qualquer tempo."26

Reconhecendo que tal preocupação se tornara obsessiva, o Narrador confessa:

"Não me sai da cabeça, hoje, o impossível de reunir aqui, em volta dessa mesa de sala do meio, aqueles eus todos que eu fui." Tal desejo, que se reporta ao passado, retorna logo ao presente: "Quem sou eu, de tantos eus que fui? Sou todos eles e sou eu só. Não sou nenhum."27

Essa pergunta nos remete às personagens de Maíra, levando-nos a ver que o entusiasmo com que o escritor recebera a subdivisão do sujeito no romance era possivelmente um mecanismo de defesa, mais do que admiração pelo ensaio. Isso veio a tornar-se evidente no novo romance, quando, num processo de negação, pôde ele mostrarse consciente de um sujeito múltiplo, ainda que pelo artifício de eliminar a sincronicidade.

Assim, pois, se até agora vimos apontando tópicos de convergência entre a cena literária e a cena analítica, a interpretação é o lugar em que diferem radicalmente uma da outra.

A

\footnotetext{
${ }^{24}$ Ribeiro. O mulo, p. 101.

${ }^{25}$ Ribeiro. O mulo, p. 105.

${ }^{26}$ Ribeiro. O mulo, p. 118.

${ }^{27}$ Ribeiro. O mulo, p. 189.
} 


\section{A B STRACT}

Resuming a polemic theme, the aim of this essay is to show some topics to which converge both the literary and the analytical scenes, plus a point wherefrom they diverge. To accomplish this aim, the following issues were brought into view: the matter of truth in poetry and fiction; the spacetime unity; the unified individual; the wandering between knowledge and truth; transferring; repetition; the significant and finally interpretation.

\section{KEY-WORDS}

truth, the space-time unity, transferring, the significant, interpretation

\section{REFERÊNCIAS BIBLIOGRÁFICAS}

Bilac, Olavo. Via Láctea: Poesia no Brasil. v. 1. Sônia Brayner (Org.). Rio de Janeiro: Civilização Brasileira, 1981.

DerridA, Jacques. El concepto de verdad em Lacan. Trad. Hugo Acevedo. Buenos Aires: Homo Sapiens, 1977.

Drummond de Andrade, Carlos. Poesia e prosa. Rio de Janeiro: Nova Aguilar, 1992.

Freyre, Gilberto. Nordeste. Rio de Janeiro: Livraria José Olympio, 1951.

Husserl, Edmund. Idées directrices pour une phénoménologie I. Trad. Paul Ricoeur. Paris: Gallimard, 1950.

LaCAN, Jacques. Le Séminaire, Livre X1. Paris: Seuil, 1973.

Leminski, Paulo. La vie em close c'est une autre chose. 4. ed. São Paulo: Brasiliense, 1993.

Melo Neto, João Cabral de. Duas águas. Rio de Janeiro: Nova Aguilar, 1994.

Miller, Jacques-Alain. Percurso de Lacan. Trad. Ari Roitman. 2. ed. Rio de Janeiro: Jorge Zahar, 1988 .

PessoA, Fernando. Poesias. 5. ed. Lisboa: Ática, 1958.

Ramos, Maria Luiza. Fenomenologia da obra literária. 3. ed. Rio de Janeiro: Forense/ Universitária, 1973.

Ramos, Maria Luiza. Interfaces. Belo Horizonte: Editora UFMG, 2000.

Ribeiro, Darcy. Maíra. Rio de Janeiro: Civilização Brasileira, 1976.

Ribeiro, Darcy. O mulo. Rio de Janeiro: Nova Fronteira, 1981.

Silvestre, Danièle et Michel. Le Transfer: Lacan; sous la direction de Gérard Miller. Paris: Bordas, 1987. 